\title{
Global to regional scale evaluation of adaptation measures to reduce the future water gap
}

\author{
Menno Straatsma ${ }^{\mathrm{a}, *}$, Peter Droogers ${ }^{\mathrm{b}}$, Johannes Hunink ${ }^{\mathrm{c}}$, Wilbert Berendrecht ${ }^{\mathrm{d}}$, Joost Buitink ${ }^{\mathrm{c}}$, \\ Wouter Buytaert $^{\mathrm{e}}$, Derek Karssenberg ${ }^{\mathrm{a}}$, Oliver Schmitz ${ }^{\mathrm{a}}$, Edwin H. Sutanudjaja ${ }^{\mathrm{a}}$, L.P. \\ H. van Beek (Rens) ${ }^{a}$, Claudia Vitolo ${ }^{\mathrm{e}}$, Marc F.P. Bierkens ${ }^{\mathrm{a}, \mathrm{f}}$ \\ ${ }^{\text {a }}$ Faculty of Geosciences, Department of Physical Geography, Utrecht University, PO Box 80115, 3508 TC, Utrecht, the Netherlands \\ ${ }^{\mathrm{b}}$ FutureWater, Costerweg $1 \mathrm{~V}, 6702 \mathrm{AA}$, Wageningen, the Netherlands \\ ${ }^{\mathrm{c}}$ FutureWater, Paseo Alfonso XIII 48, Cartagena, Spain \\ d Berendrecht Consultancy, Stakenbergerhout 107, 3845 JE, Harderwijk, the Netherlands \\ ${ }^{\mathrm{e}}$ Faculty of Engineering, Department of Civil and Environmental Engineering, Imperial College London, Skempton Building, South Kensington Campus, London, SW7 2AZ, \\ $U K$ \\ ${ }^{\mathrm{f}}$ Deltares, Utrecht, the Netherlands
}

\section{A R T I C L E I N F O}

\section{Keywords:}

Global hydrology

Water allocation

Web-based simulation

Adaptation options

Investment costs

\begin{abstract}
A B S T R A T
The global water gap, water demand minus water supply, is expected to increase through 2100, negatively affecting agriculture, industry and households. Adaptation measures are necessary, but projections on their effectiveness and costs are currently unavailable. Here, we present an adaptation evaluation framework aimed at closing the water gap, which is applied offline at the global scale, and made available for regional decision making as a web service. It includes climate change and socioeconomic scenarios over the 21st century as drivers for global projections of water supply and demand. The transient water gap was calculated for 1604 water provinces globally and we determined the water gap reduction that could be achieved by three increasingly involved sets of adaptation measures. The median annual adaptation costs amount to $1.4-1.6 \%$ of the GDP per affected water province. The interactive web-based simulation allows users to include information that is not available at the global scale.
\end{abstract}

\section{Introduction}

Water scarcity presents a serious risk to people, industry, livestock and agriculture (Vörösmarty et al., 2000; Haddeland et al., 2014). The water gap - defined as the difference between gross water demand and water supply from rivers, lakes and reservoirs, and renewable groundwater - will likely increase due to climatic and socioeconomic change. Climate change is expected to affect a basin's water supply to varying degrees, while water demand is likely to increase in response to a growing population, irrigation needs, and industrial activities (Hanasaki et al., 2008; Falloon and Betts, 2010; Van Beek et al., 2011; Droogers et al., 2012; Wada et al., 2012; Gain and Wada, 2014). Reducing the water gap requires adapting current practices and infrastructure to increase the water supply, or to reduce the demand.

The term "adaptation", as used here, refers to measures to reduce the growing water gap, and includes counter measures for both climate and non-climate factors. These adaptations refer in our case to non-time varying intervention scenarios in either supply or demand of water. We do not model the adaption process, whereby humans observe trends and triggers, and respond over time. Adaptation options are costly and have a lasting effect on the local hydrology (Hallegatte, 2009). Funding for adaptation is increasing on the global scale, especially after ratification of the 'Paris Agreement' of the COP21 meeting. Countries agreed to finance both adaptation and mitigation to battle the adverse effects of climate change, but they also recognized that public grants-based resources are especially important for adaptation, because contrary to mitigation, it is more difficult to attract private funding for adaptation. The share of funding needed for adaptation will thus increase substantially up to 2020, especially for the most vulnerable nations, being facilitated through various funds such as the Least Developed Countries Fund, the Special Climate Change Fund, the Adaptation Fund and the Green Climate Fund (Donner et al., 2011). In this light, it is essential to

\footnotetext{
* Corresponding author.

E-mail address: m.w.straatsma@uu.nl (M. Straatsma).
} 
provide policy and decision makers with reliable information regarding the future water gap, that is, projections of the water supply and demand, as well as investment and maintenance costs required to reduce the water gap. This information is required at two distinct spatial scales. Global scale assessments are required for policy making, which need to rely on globally available data and predefined assumptions regarding adaptations applied at that scale. They inform policy makers about the consequences for the global hydrology under different climatic and socioeconomic projections, the effectiveness of adaptations in reducing the water gap, and how these factors are distributed over the globe. Such global scale assessments can be predefined and models can be run without interaction with the policy makers that use the information, similar as to the IPCC models. At the regional scale, similar assessments are required for decision making regarding financing of adaptations to reduce the water gap, however tailored to the regional boundary conditions. This information can only be provided by an interactive simulation framework, as numerous inputs need to be configurable, e.g. priorities for water users, the magnitude of a range of adaptations, and limitations from water treaties.

It is convenient to implement such interactive simulation frameworks as web services, to facilitate decision-maker access and leverage cloud technologies (Buytaert et al., 2012). Water resources modeling using web-based simulation have the potential to provide added value from climate-related data with respect to water scarcity. Examples of hydrology-related web services include, but are not limited to discovery and visualization of basic hydrologic data (Ames et al., 2012), web-based simulation of eco-efficiency for water use systems combining the economic and environmental viewpoints in a single framework (Arampatzis et al., 2016), and the online coupling of an atmospheric model to a hydrologic model (Goodall et al. 2011, 2013). See Vitolo et al. (2015) for an overview of web-based technologies and Byrne et al. (2010) and Buytaert et al. (2012) for the (dis-)advantages of web-based simulation. Interactive simulation frameworks, which enable users to enter local information or configure model simulations that are run on a server and visualized in a web browser, have been developed for related application domains, for instance for modelling of catchment hydrology (Rajib et al., 2016), groundwater pollution risk (Sege et al., 2018), and surface water quality (Walker and Chapra, 2014). Existing tools however, do not enable web-based simulation of water scarcity adaptation scenarios considered here and do not have a global coverage.

A new computational framework should enable the generation of the required information at both scales. The global occurrence of water scarcity and its detrimental effects have been studied extensively (Alcamo et al., 2003; Hanasaki et al., 2008; Shen et al., 2008; Haddeland et al., 2014; Kummu et al., 2016; Dalin et al., 2017), but global studies on the effectiveness and cost of adaptation are rare. Kirshen (2017) carried out a scenario analysis at the country level to estimate the cost of water supply production facilities necessitated by climate and socioeconomic changes by 2030 . He calculated the costs of groundwater, reservoirs, desalination, and wastewater treatment over ten regions. Total adaptation costs amounted to 531 billion US\$ over the 2000-2030 period. Fischer et al. (2007) approached the water scarcity issue from the perspective of climate change mitigation and found that annual irrigation costs would be 10 billion US\$ lower in 2080 due to a mitigation scenario as compared to unmitigated climate change. Ward et al. (2010) calculated the cost of climate change adaptation for industrial and municipal water over 281 water provinces. They reported annual adaptation cost totaling 12 billion US\$ globally, which is $16 \%$ of the cost without climate change. However, we are not aware of any study that projected the effectiveness and costs of adaptation over the whole 21st century at the global scale, including water demand from all major sectors (irrigation, domestic, industrial, and environmental flow demands). The long temporal horizon is particularly important, because of the large investment costs of adaptation measures. None of the existing global studies enabled the evaluation of adaptation options under user configured scenarios, for instance in a web-based modelling environment. At basin scale though, optimization methods for the sustainable management of water have been made available through a web-based client-server implementation. For example, Cetinkaya et al. (2008) provided an online interface to a decision support system for a river basin in Turkey, which included optimization of four different adaptations to save water and reduce sectoral water gaps.

Here we present a new modelling framework to answer two key questions. Firstly, what is the magnitude and the global spatial distribution of the future water gap and to what can adaptations reduce this gap and to what price? Secondly, how can we enable decision makers through a web-based modelling environment to evaluate regional investment scenarios to close the water gap? We subsequently discuss the limitations to our modelling framework and other related frameworks that need to be overcome for improved policy and decision making. Our framework uses the existing PCR-GLOBWB global hydrology and water resources model (Sutanudjaja et al., 2018) coupled to a user configurable module that calculates for each water province the water marginal cost curve (WMCC). Here, a water province, also known as a food producing unit (Veldkamp et al., 2015; Miina et al., 2016), represents the intersection of the hydrological boundaries of river basins with the administrative boundaries of countries and provinces. The WMCC summarizes the microeconomic analysis of the cost and effectiveness of a range of existing technical measures to reduce the projected water gap in an area and provides a concise representation of the cost effectiveness of adaptation options (2030WRG, 2009). The underlying assumption of the WMCC is that adaptations that are cheap, or that even create a financial benefit, would be implemented first. Regional relevance is maximised if the spatial scale of the analysis matches that of the decision-making process. Our method builds on previous work (Fischer et al., 2007; Ward et al., 2010; Kirshen, 2017) in several ways: (1) we extended our time horizon to the end of the 21st century; (2) we increased the number of water provinces from 281 to 1604 providing increased resolution and global coverage; (3) we estimated the cost and effectiveness of three sets of adaptation options to determine the WMCC and compared these results to a business-as-usual scenario with no adaptation measures; (4) we provide a web-simulation framework that enables users to create locally relevant information using the same modelling framework used for global scale assessment, which is the Water2Invest web tool (http://w2i.geo.uu.nl).

\section{Methods}

\subsection{Modelling framework}

The software framework produces the water marginal cost curves per water province based on the selected climate and socioeconomic scenarios. The annual costs of water per type of adaptation option are used as input and additional available water (reduction of the water gap) is part of the output. Gross water demands include all water requirements for irrigation (evaporation and transport losses), and consumption and return flows of industrial, domestic use (Wada et al., 2011b) and environmental flow requirements set to $20 \%$ of the pristine discharge. We limited the scope of the framework to physical availability of water, leaving out the effects of water quality (Scanlon et al., 2007), water temperature (van Vliet et al., 2013), and future limitations for specific land use due to flood risk and soil subsidence (Temmerman et al., 2013). That is not to say that these aspects are unimportant, but the integration of these components remains challenging, especially at global scale.

\subsubsection{Water supply}

Water supply is calculated using the PCR-GLOBWB global hydrology and water resources model, which simulates water storages and fluxes of the terrestrial part of the hydrological cycle at a spatial resolution of 5' gridcells in latitude and longitude (Van Beek et al., 2011; Wada et al., 2011b; Sutanudjaja et al., 2018), see SI1 for details. Meteorological forcing, including time series of daily rainfall and temperature fields, 
between 2006 and 2099 is derived from five global circulation models (GCMs: GFDL-ESM2M, Hadgem2-ES, IPSL-CMA5-LR, MIROC-ESM-CHEM, NorESM1-M) that participated in the Coupled Model Inter comparison Project (CMIP5) (Taylor et al., 2012) and the ISIMIP intercomparison project (Schewe et al., 2014; Warszawski et al., 2014). The GCM time series were bias-corrected by the method of Hempel et al. (2013). The PCR-GLOBWB runoff and baseflow fluxes were bias-corrected using measured discharge from the Global Runoff Data Centre (GRDC) (GRDC, 2016).

The water supply thus calculated only includes renewable water resources. Fossil groundwater withdrawal is limited to twice the longyear average groundwater recharge. This value is thought to provide a good balance between avoiding the extraction of non-renewable water resource on the one hand, and account for interannual variation in groundwater storage and to allow limited depletion rates in drier years on the other hand. As a consequence, the resulting withdrawal in semiarid areas with limited recharge is much smaller than previous studies (Wada et al. 2011b, 2012) that found withdrawals exceeding the recharge by a factor 50 . It is therefore important to note that water gap calculations pertain to conditions that are intended to be close to sustainable.

Monthly hydrological fluxes (time series of surface runoff, interflow, baseflow, groundwater recharge and storage, actual and potential evapotranspiration) from PCR-GLOBWB are averaged over the water provinces, which are the basic units for water gap and adaptation analysis in the framework. The water provinces are based on the overlay of the World Administrative Division map (ESRI, 2011) and the major river basins (Lehner et al., 2008). Provinces smaller than $20000 \mathrm{~km}^{2}$ are merged iteratively while preserving national boundaries (SI2). The water province topology is derived from the flow direction map and the annual average discharge over the 1980-2010 period (GRDC, 2016) (SI3).

For each of the four RCPs and five GCMs, the framework simulates the global water supply at 5' by forcing PCR-GLOBWB with daily precipitation and temperature fields. These 20 runs required around 100000 core hours on the Dutch national supercomputer Cartesius. To limit the computational demand in the interactive adaptation planning, the water gap and adaptation analysis was executed on a global composite of the PCR-GLOBWB output from the five GCMs. The composite was created by using the output of PCR-GLOBWB from a single GCM for each river basin. The GCM-PCR-GLOBWB combination was selected whose output ranked third out of five in terms of average discharge over the 2006-2099 period. In this way, the framework analyzes a representative sample from the GCM-uncertainty range and filters out outlier GCMs for each basin.

\subsubsection{Water demand and allocation}

Water demand and allocation per water province is computed using the lumped Water and Climate Adaptation Model (WatCAM) (Buitink et al., 2016), which is inspired by more complex distributed water allocation and optimization models such as WEAP (Yates et al., 2005) and MIKE-BASIN (DHI, 2012) (see Supplemental information (SI), SI-S3 for details). WatCAM is applied on each node of the network of water provinces. Water is allocated to the four main demand types within a water province based on priorities. Similar to the WEAP model, priorities range between 1 (high priority) and 99 (low priority). In case of water shortage, the priorities determine the percentage of demand which is met (more details in SI-S3.5). The allocation depends on the ratios between the priorities of the different water demand sectors. The priority values do not have an absolute quantitative meaning, but allow a step-wise successive reduction in allocation priority. For more details on the calculation methods of WatCAM please refer to SI-3 and Buitink et al. (2016).

Monthly time-series of water demands are computed for each water province, for: (a) irrigation, from the irrigation equipped area (Portmann et al., 2010), RCP-dependent potential evapotranspiration from
PCR-GLOBWB, and a country-specific efficiency factor, (b) industry, from the SSP-dependent GDP and the GDP per capita (FAO-AQUASTAT, 2016) (c) domestic use, from the population size, and GDP per capita based on the method of van Vuuren et al. (2007) and the SSP database (IIASA, 2015), and (d) environmental flow demands, set to $20 \%$ of the naturalized mean monthly flow. Given the lack of a globally accepted minimum for environmental flow, our $20 \%$ setting is well within the range of $10-60 \%$ given by Tennant (1976), and it qualifies as a river that is classified as 'largely modified' in the environmental flow software of Smakhthin and Eriyagama (2008). In the allocation scheme, the environmental flow requirement was treated as a water demand rather than a hard constraint, similar to demands from other sectors (SI-3.1). With the inclusion of environmental flow we deviate from other studies on water allocation (Wheeler et al., 2018) or water scarcity (Greve et al., 2018), but we also recognize that additional demands can be posed based on the variable flow method proposed by Pastor et al. (2014), which was applied by Veldkamp et al. (2017).

\subsubsection{Effectiveness and cost}

Generating water marginal cost curves (WMCC) requires quantifying the additional water that becomes available from an adaptation measure, and the cost of that measure. Unfortunately, no global database exists on country-specific costs of adaptation options in water resources, although scattered information is available, e.g. (WCoD, 2000; Hellegers, 2006; Trieb and Müller-Steinhagen, 2008; 2030WRG, 2009; Immerzeel et al., 2011). For watersheds in South Africa, Brazil, India and China, the 2030 Water Resources Group made an in-depth analysis of the costs of over 35 adaptation options that are often unique to a specific country (2030WRG, 2009). When the same measures were found useful in more than one country, they often found a factor three difference or more in the cost per cubic meter of water gained between countries due to differences in efficiency of the adaptations. For example, the annual costs for the "new dams" option ranges from $0.06 \mathrm{US} \$ / \mathrm{m}^{3} / \mathrm{y}$ for China to $0.16 \mathrm{US} \$ / \mathrm{m}^{3} / \mathrm{y}$ for South Africa and aquifer recharge ranges from 0.03 $\mathrm{US} \$ / \mathrm{m}^{3} / \mathrm{y}$ for India to $0.14 \mathrm{US} \$ / \mathrm{m}^{3} / \mathrm{y}$ for Brazil. This clearly shows the need for local scale parameterization and interactivity, which we provide in the online tool. However, there is no overview available of these costs per country and the global calculations were carried out with global defaults, which were based on averages of cost estimates in the references mentioned above. The default annual costs per cubic meter additional water (US $\$ / \mathrm{m}^{3} / \mathrm{y}$ ) were set to the following values for each of the eight adaptation options: (1) 0.02 for improved agricultural efficiency, (2) 0.04 for reuse of irrigation water, (3) 0.05 for increase in reservoir capacity, (4) 0.3 for reuse of urban and industrial water, (5) 1 for desalination, (6) 0.1 for reduction of irrigated area, and 7,8) 2.0 for the reduction of urban demand and industrial demand. These annual values include costs to construct and maintain the infrastructure through 2099. Note that in reality, the outlay would be represented as a stepwise function with construction followed by maintenance costs, but the framework lumps these costs in an annualized manner for simplification.

\subsection{Global scale assessment}

Using the framework, we calculated global scale 21st century projections of the development of the water gap under two scenarios incorporating climate and socio-economic factors, assuming either optimistic (RCP2.6/SSP1; s1) or extreme (RCP8.5/SSP5; s5) trends. These two scenarios comprise the envelope of RCP-SSP combinations regarding water availability. We chose the RCP2.6 climate change scenario and SSP1 socioeconomic scenario (Vuuren et al., 2014) (denoted as 's1') as the lower limit of change, and the RCP8.5 plus SSP5 scenario as the upper limit (denoted as 's5'). In the global application, we explored four adaptation scenarios for both RCP-SSP combinations. We applied the adaptation scenarios uniformly across all water provinces to facilitate comparison of the efficiencies of the adaptations to reduce the 
water gap. The reduction in water gap per adaptation option is the result of the water allocation. For example, the enlargement of reservoir capacity only affects the amount of available water when there is sufficient water available within the river basin. Once the additional available water is estimated, its additional volume is multiplied with the annual cost per cubic meter to obtain the annual costs (investments, transaction costs or reduced revenues) of obtaining the additional water. The uniform application of adaptations was chosen due to a lack of local preferences and we acknowledge that there are differences in the feasibility of our chosen measures among the water provinces. In all scenarios, water allocation priorities $1,10,30,50$ were given to the domestic, industrial, irrigation and environmental demand, respectively. Thus, for both s1 and s5, we ran WatCAM between 2006 and 2099 with the following adaptation scenarios:

1. BAU: the baseline scenario consists of business as usual (for $\mathrm{s} 1$ and s5), in which no adaptations are implemented.

2. Imp.Agr: the improved agriculture scenario assumes that a combination of improved irrigation practices was implemented that leads to a reduction of the volume of non-consumed water (i.e. return flows) of $40 \%$.

3. Inc-Sup: this scenario consists of measures that increase the water supply: (1) Expanding reservoir capacity and increase salinization to increase the water supply. Reservoir capacity was expanded with 1000 MCM (mega cubic meter) in the model, although not all water provinces have the water available to fill such reservoirs. Since the total costs are calculated from the water gap reduction, no penalty is given for overcapacity. (2) The desalination capacity was extended with $1000 \mathrm{MCM} /$ year for all WPs bordering the sea, which is a comparable amount as the $48600 \mathrm{MCM}$ /year desalination capacity that Hanasaki et al. (2016) found as a maximum for the period 2041-2070. (3) The reuse of water within the water provinces is increased, from 20 to $60 \%$ for irrigation, and from 50 to $80 \%$ for domestic and industrial water. By comparison, Jägermeyr et al. (2015) mapped out global beneficial irrigation efficiencies, which were less than 30\% in South Asia and more than 60\% in Europe and North America.

4. Red.Dem: this scenario comprises the reduction of the urban and domestic demands. Red.Dem reduces the demands by $15 \%$, to be achieved by enhancements in the industrial processes and severe water saving measures in the domestic sector.

Using adaptation options 2 to 4 as successive combinations $(2,2+3$, and $2+3+4$ ) we analyzed to what extent the water gap could be closed in each water province. Note that we did not look at optimization of the spatial configuration of adaptation options within a river basin. WatCAM output at the water province scale was post-processed into continental-scale WMCCs, and maps of the adaptations required to close the water gap. For the sake of comparability between countries and regions, the framework uses globally uniform and lumped costs of 0.02 , 0.3 , and $2 \mathrm{US} \$ / \mathrm{m}^{3} / \mathrm{y}$ for the Imp.Agr., Inc.Sup., and Red.Dem. adaptations, respectively. These comprise aggregated costs for the eight adaptation options given in section 2.1. Given the variation in costs between countries (WCoD, 2000; Hellegers, 2006; Trieb and Müller-Steinhagen, 2008; 2030WRG, 2009; Immerzeel et al., 2011) the range of costs for our scenarios can be expected to vary as $0.005-0.1,0.1-0.5$, and $0.5-2.5 \mathrm{US} \$ / \mathrm{m}^{3} / \mathrm{y}$ for Imp.Agr., Inc.Sup., and Red.Dem. adaptations. The adaptations' effectiveness was determined from the fraction of the BAU water gap that was closed by the measures. Annual costs were summed up per adaptation for each scenario, and presented as maps depicting the cost as a fraction of the water provinces' GDP.

\subsection{Local scale assessment: web-based simulation framework}

We assembled the data and analysis software developed for the global water gap and adaptation analysis into a web-based simulation framework that allows analyzing measure effectiveness and efficiency for individual water provinces interactively, such that local detail (unit cost and effectiveness) may be added. The accompanying website, http://w2i.geo.uu.nl, is based on a Drupal frontend and a Postgresql database in the backend to store maps and time series. WatCAM runs in the backend on Python 2.7. It has two main components. Firstly, it serves basic data that affect the water gap, including CMIP5 temperature and precipitation fields for all RCP scenarios, PCR-GLOBWB runoff, discharge and actual evapotranspiration, and the sectoral water demands per SSP. These data are also used as input for WatCAM. Secondly, the adaptation investigation allows the selection of a single water province and the subsequent analysis of eight adaptation measures and their effect on the water marginal cost curve under all possible combinations of RCP and SSP scenarios. The cost per cubic meter additional water can be specified for each type of adaptation measure and the joint effect of every possible combination of individual measures analyzed by calculating WMCCs. Also, inter-basin water transfer can be simulated through additional external flow to the water province. The tool is not meant for the general public, but for students, experts and professionals in water science and management. For these users, the tool should be rather intuitive and self-explanatory, while the HELP buttons contain additional explanations. We illustrate the functionality by means of an assessment of the area around Valencia in Spain.

\section{Results}

\subsection{Water gap under the business as usual scenario}

The 2015 water gap, calculated by averaging over the monthly time series over the years 2006-2025, showed a number of hotspots for the BAU scenario, most notably in the south and west of the United States, the Middle East and North Africa, the basins of the Ganges and the Indus, and China's coastal zone (Fig. 1a). By comparison, the 2090 BAU water gap, averaged over the years 2080-2099, was more extensive and larger for both the $\mathrm{s} 1$ and the 55 scenario (Fig. 1b, c). The total surface area of the water provinces with a water gap amounts to $11.010^{6} \mathrm{~km}^{2}$ for the current state, which is $8.7 \%$ of the $13210^{6} \mathrm{~km}^{2}$ of the terrestrial land mass minus Antarctica and Greenland considered in this study. The percentage increases to $8.9 \%$ and $12.0 \%$ for s1 and s5 in 2090, respectively. An additional 0.2 and $2.2 \%$ of the surface area will experience a new water gap larger than $10 \mathrm{~mm} / \mathrm{y}$ in 2090 for $\mathrm{s} 1$ and s5, respectively. For the 182 water provinces with a water gap projected for 2015 and 2090 , the median value for the water gap is expected to increase from $19 \mathrm{~mm} / \mathrm{y}$ in 2015 to 28 and $48 \mathrm{~mm} / \mathrm{y}$ for the s1 and s5 projection, respectively. Under the s1-BAU scenario, the global water gap peaks around 2050 at $930 \mathrm{~km}^{3} / \mathrm{y}$ and declines to $800 \mathrm{~km}^{3} / \mathrm{y}$ in 2100 , still $200 \mathrm{~km}^{3} / \mathrm{y}$ above the 2006 value (Fig. 2). Contrastingly, for s5-BAU, the gap increases linearly to $1400 \mathrm{~km}^{3} / \mathrm{y}$.

The patterns in sectoral water shortage are in line with previous studies (Wada et al., 2011b; Haddeland et al., 2014; Prudhomme et al., 2014) in which the same hotspots are present, but there are also differences because we address the combined demands of industry, households, irrigation, and environmental flow, and we aggregate over the water provinces instead of looking at cell-specific or country-average values. Table 1 compares global values of our study with other studies, showing comparable results, except for the lower estimates of domestic water demand. These can be explained by the fact that WATCAM uses a logarithmic instead of a linear relation between GDP per capita (GDPC) and gross domestic water demand from AQUASTAT. This results in lower estimates for more developed countries (higher GDPC) than in most studies that use linear relationships. We note however that regardless of the fitted relation, the scatter is very large. It is also worth noting that in our model actual water withdrawal is lower than gross demand as it includes deficits (water demand not met by supply) as well as water recycling that reduces water withdrawal. 
a) 2006 - 2025
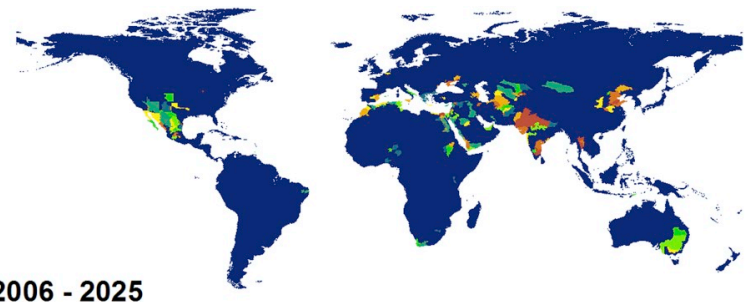

b) 2080 - 2099

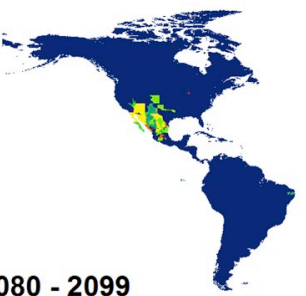

SSP1 and RCP2.6

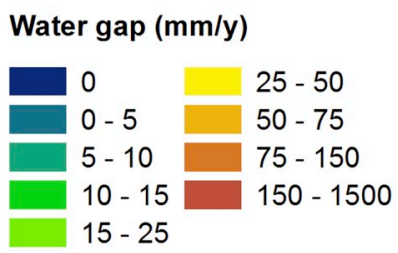

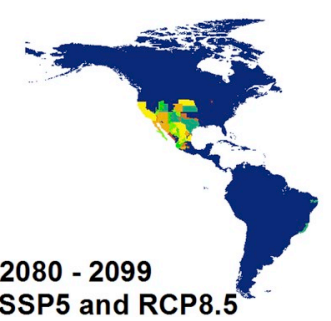

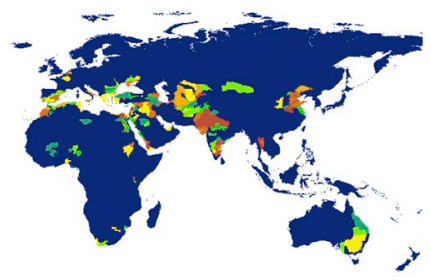

Fig. 1. Current and future water gap per water province. Total annual water gap in the period 2006-2025 (mm/y) (a) in the period 2080-2099 for the SSP1 and RCP2.6 scenario (b), and in the same period under the SSP5 and RCP8.5 scenario (c).

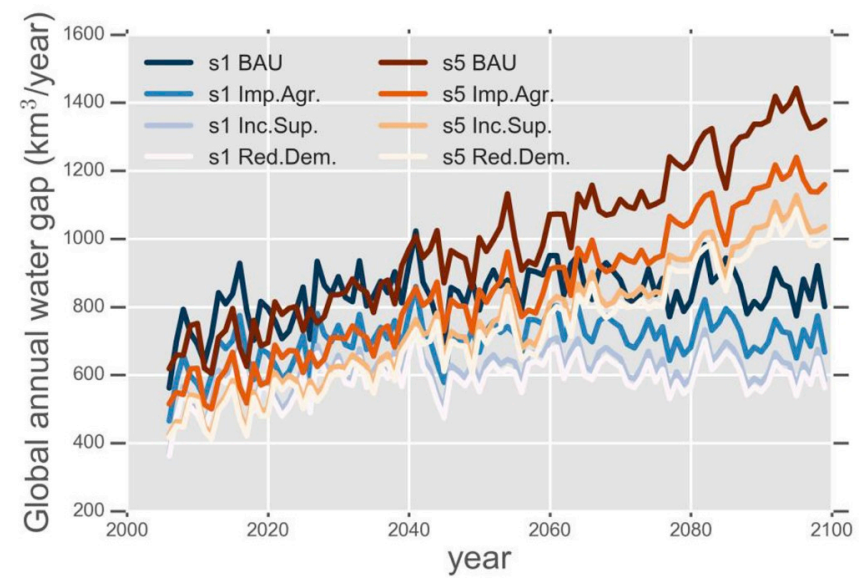

Fig. 2. Envelope of the global annual water gap $\left(\mathrm{km}^{3}\right)$ between 2006 and 2099 under the two most extreme combinations of climate change and socioeconomic development ( $\mathrm{s} 1=\mathrm{RCP} 2.6 / \mathrm{SSP} 1$; $\mathrm{s} 5=\mathrm{RCP} 8.5 / \mathrm{SSP} 5)$. The three adaptations options (section 2.3) consist of improving the water efficiency of agriculture (Imp.Agr.), combining the previous with increasing the supply by increasing the reservoir capacity (Inc.Sup.), and combining the previous two options with a reduction in the water demand (Red.Dem.). The business as usual scenario (BAU) has no adaption measures implemented. Note that transients represent long-term trends of climate change, with climate variability superimposed. (For interpretation of the references to color in this figure legend, the reader is referred to the Web version of this article.)

\subsection{Effects of adaptation measures}

The modelled global annual water gap ranges from $360 \mathrm{~km}^{3} / \mathrm{y}$ when all adaptation options are implemented under the s1 scenario in 2006 (s1-Red.Dem; Fig. 2) to $1400 \mathrm{~km}^{3} / \mathrm{y}$ for the s5 scenario without any adaptations implemented in 2090 (s5-BAU). These results suggest that the future global water gap cannot be closed using a reasonable set of adaptation measures and predominantly renewable water resources. Note that the times series for the s1 and s5 BAU scenarios largely overlap through the early 2040s, causing the time series for a given adaptation scenario to overlap for these two conditions as well. The differences in the values between the business as usual scenarios of s1 and s5 in 2006 represents yearly variation from the weather generated in the GCMs. It is only after 2045, when the s1 and s5 BAU scenarios begin to deviate markedly, that relative differences in impact on the water gap grow larger between the two conditions for a given adaptation scenario. This shows the increased influence of climate and socioeconomic change, which amounts to a difference of $458 \mathrm{~km}^{3} / \mathrm{y}$ in 2090 between s1-BAU $\left(862 \mathrm{~km}^{3} / \mathrm{y}\right)$ and $\mathrm{s} 5-\mathrm{BAU}\left(1320 \mathrm{~km}^{3} / \mathrm{y}\right)$. The reduction by adaptation scenarios of the water gap is larger for the s5 scenario than for the s1 scenario. The additive adaptation measures reduce the water gap by 140,230 , and $250 \mathrm{~km}^{3} / \mathrm{y}$ for the s1 scenario and by 150,250 , and $270 \mathrm{~km}^{3} / \mathrm{y}$ for the s5 scenario when averaged over the period 2006-2090. The combination of mitigating climate change (i.e. staying on the RCP2.6 scenario, s1) and adaptation (Red.Dem. adaptation) lowers the 20-year average water gap from $759 \mathrm{~km}^{3} / \mathrm{y}$ in 2015 to $605 \mathrm{~km}^{3} / \mathrm{y}$ in 2090 .

One can see that the proposed adaptation options are far from closing the water gap. Furthermore, the number of water provinces experiencing a gap grows, with 95 additional water provinces requiring adaptation in the 55 scenario compared to the $s 1$, as can be seen from the changing spatial extents (Figs. 1-3, S8). Given that in reality environmental flow requirements are often already violated and droughts affect agriculture and industry, our results show that complete closure of the water gap is elusive. Even if one analyzes the results using a $75 \%$ water gap closure as a substitute metric (Fig. 3), there are still 130 out of 1604 water provinces under scenario $\mathrm{s} 1$ where all combined options close less than $75 \%$ of the water gap, and 175 under the s5 conditions.

The water marginal cost curve (WMCC) per continent (insets in Fig. 3) indicates the effectiveness of the three options, and the size of the remaining water gap. The horizontal axis of the WMCC shows the additional annual water (in $\mathrm{km}^{3} / \mathrm{y}$ ) that becomes available or is being saved due to each of the three different adaptation scenarios. The vertical axis shows the (ordinal scaling of the) costs per additional cubic meter of water that becomes available (in USD $/ \mathrm{m}^{3}$ ). For example, in North America the water gap is equal to 70 and $150 \mathrm{~km}^{3} / \mathrm{y}$ for the $\mathrm{s} 1$ and s5 scenario, respectively. In the s1 scenario, $25 \mathrm{~km}^{3} / \mathrm{y}$ can be gained from the three increasingly expensive adaptation options, compared to $50 \mathrm{~km}^{3} / \mathrm{y}$ in the s5 scenario. The reason for the larger reduction in water gap size in the s5 scenario is the higher temperature, and the coupled higher evaporation of excess water used for irrigation, which causes the measures Imp.Agr and Red.Dem to be more effective. Even though the adaptations provide additional water in the $s 5$ scenario, the remaining water gap of $90 \mathrm{~km}^{3} / \mathrm{y}$ exceeds the one from the $\mathrm{s} 1$ scenario. The largest water gap is found in Asia, which includes the water scarcity hotspots of the Middle East, India and China. South America has the smallest water gap, and also the largest relative closure of the water gap (95 and 55\%, for the s1 and s5 scenario, respectively). 
Table 1

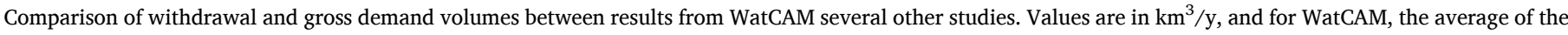
baseline period is reported.

\begin{tabular}{|c|c|c|c|c|c|}
\hline Attribute & Period & Domestic & Industrial & Irrigation & Reference \\
\hline withdrawal & 2006-2025 & 154 & 813 & 2057 & this paper \\
\hline gross demand & $2006-2025$ & 172 & 919 & 2765 & this paper \\
\hline withdrawal & $2000-2016^{\mathrm{a}}$ & 377 & 777 & 2659 & FAO-AQUASTAT (2016) \\
\hline gross demand & 2010 & $\sim 450$ & $\sim 725$ & - & (Wada et al., 2016) (H08) \\
\hline gross demand & 2010 & $\sim 350$ & $\sim 775$ & - & (Wada et al., 2016) (WatGAP) \\
\hline gross demand & 2010 & $\sim 470$ & $\sim 800$ & - & (Wada et al., 2016) (PCR-GLOBWB) \\
\hline withdrawal & $2000^{\mathrm{b}}$ & $\sim 460$ & $\sim 730$ & 3214 & (Hanasaki et al., 2013b, a) \\
\hline gross demand & & 328 & 752 & 2628 & Wada et al. (2011a) \\
\hline withdrawal & 2000 & 390 & 777 & 2658 & Shen et al. (2008) \\
\hline withdrawal & 1995 & - & - & 2810 & Hanasaki et al. (2008) \\
\hline gross demand & 1995 & - & - & 2452 & Döll and Siebert (2002) \\
\hline
\end{tabular}

a Based on statistics within this time period.

b 1971-2000 for irrigation. Note, Wada (2016) is a comparative study, model names are given in brackets.

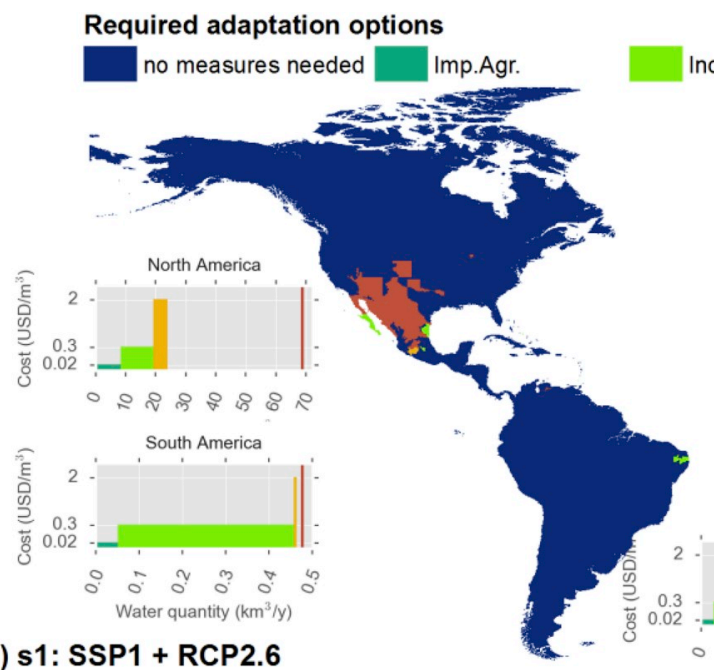

a) s1: SSP1 + RCP2.6

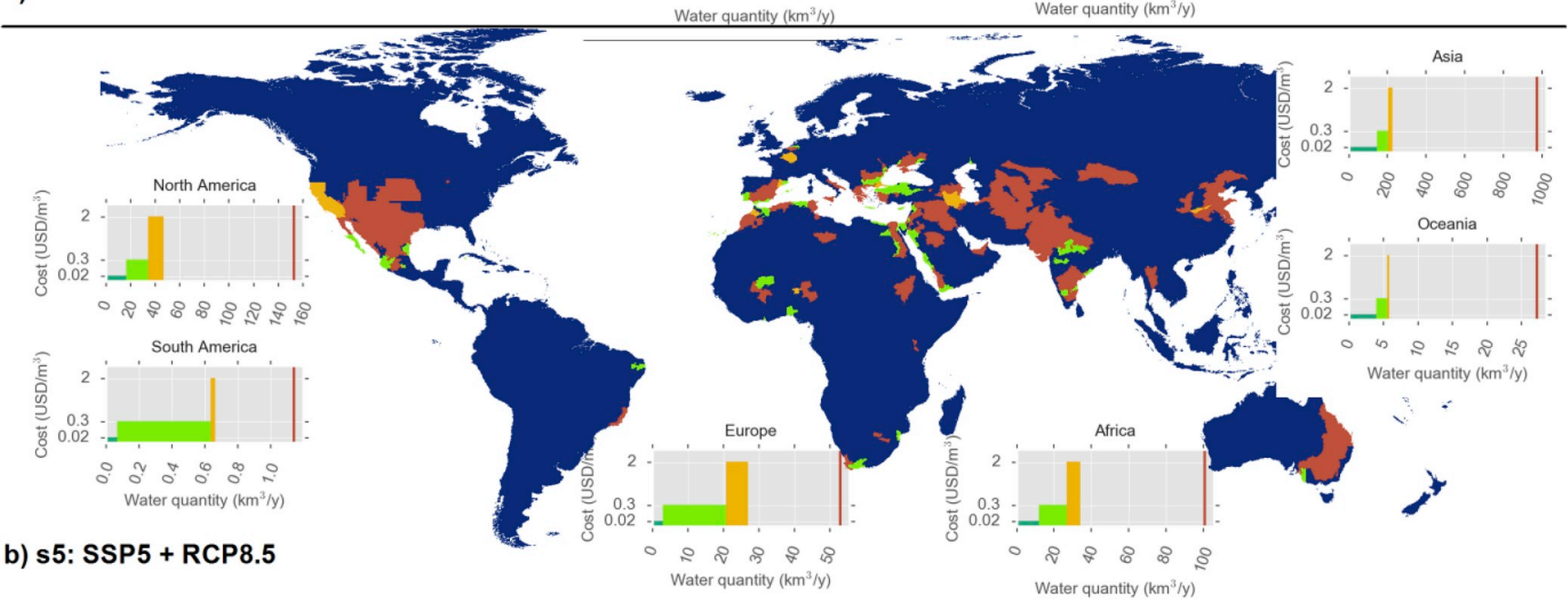

Fig. 3. Spatial distribution of the required adaptation options to close $75 \%$ of the water gap for the $s 1$ scenario (a) and for the s5 scenario (b) in 2090 . The brown color in the maps indicates where the complete set of adaptation options cannot provide enough water. The insets show the water marginal cost curves: plotting the increased closure of the water gap quantity (x-axis) versus the cost of the adaptation per cubic meter of water (y-axis). The color scheme of the bars is identical to the map, the vertical brown line denotes the water gap that cannot be met with the considered scenarios. Note that the horizontal axes of the insets strongly differ between continents, and between scenarios. (For interpretation of the references to color in this figure legend, the reader is referred to the Web version of this article.)

\subsection{Relative adaptation costs}

The adaptation costs of the implemented options comprise a substantial percentage of the water provinces' GDP of 2015 (Fig. 4). Delayed implementation of measures in order to reduce cost was not considered for simplicity. The median relative cost of the adaptations for the water provinces with water shortage is $1.6 \%(\mathrm{n}=184)$ for the $\mathrm{s} 1$ scenario, and $1.4 \%(n=244)$ for the s5 scenario, with s5's lower percentage caused by a relatively higher GDP of the additional water provinces under stress under s5. From the 1604 water provinces, 51 and 


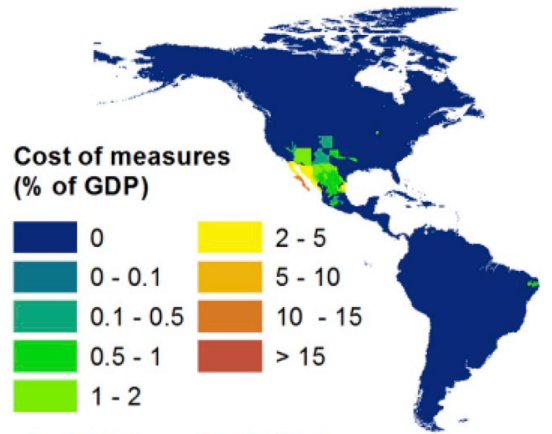

a) s1: SSP1 and RCP2.6

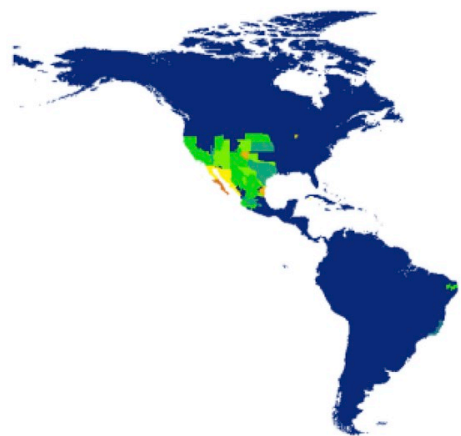

b) s5: SSP5 and RCP8.5
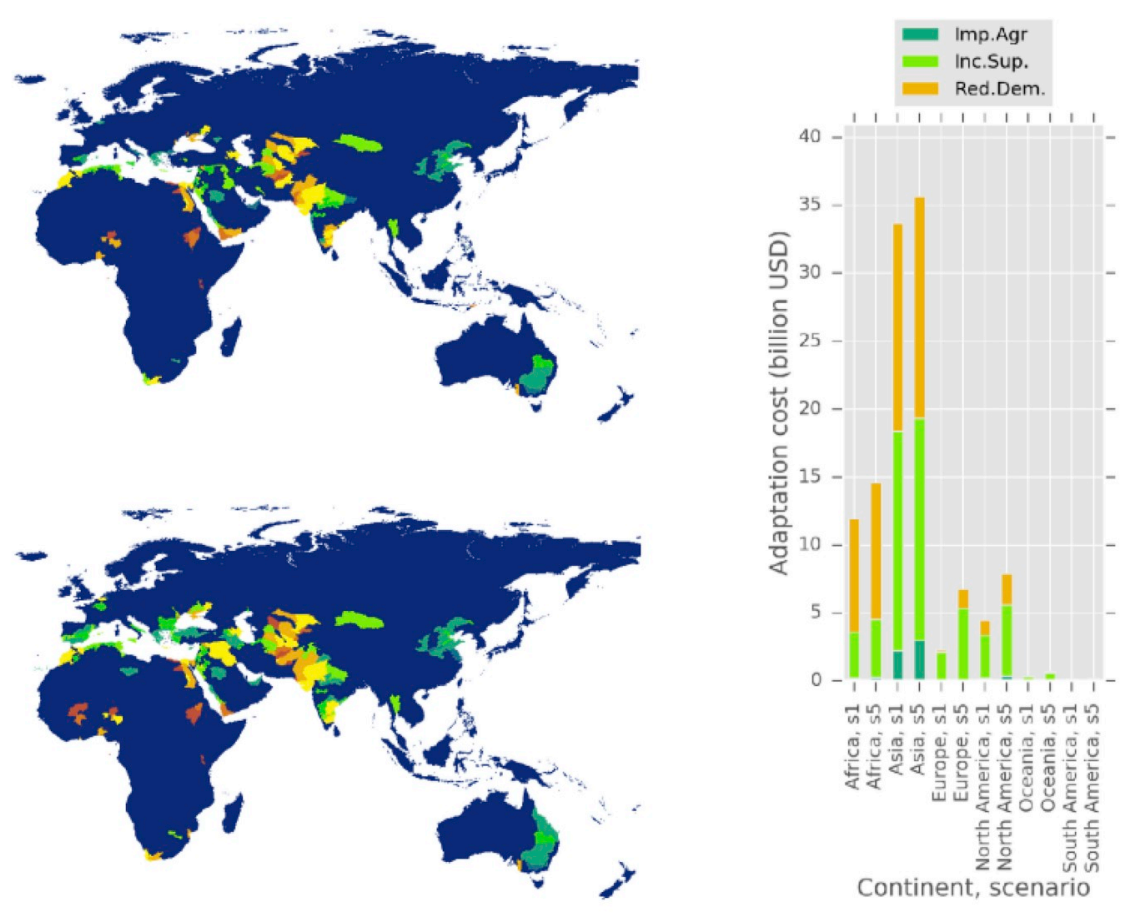

c) Adaptation costs

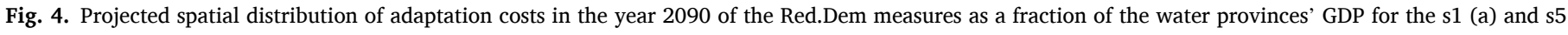

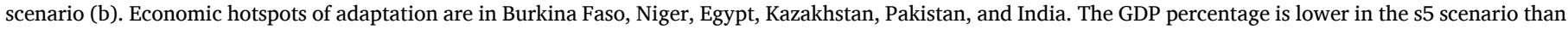

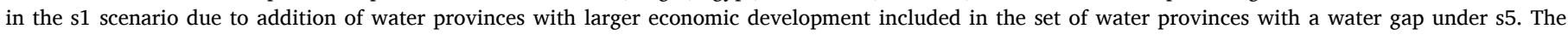

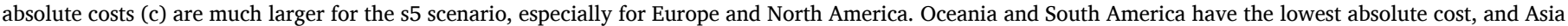
the highest. (For interpretation of the references to color in this figure legend, the reader is referred to the Web version of this article.)

59 water provinces have to invest more than $5 \%$ of their GDP to implement the adaptations for the s1 and s5 scenario, respectively. These are mainly located in the basins of the Indus, Ganges, Amu Darya and Syr Darya river basins, and along the lower reaches of the Nile River. The relative costs in the USA and Europe remain below 5\%, independent of the future scenario. To put these percentages in perspective, OECD countries spend on average $5.2 \%$ of their GDP on education (OECD, 2016). The global annual adaptation cost amounts to 79 (s1), and 115 (s5) billion US\$/yr. Asia requires the largest investments (Fig. 4c), maximised at 36 billion US\$/year in the s5 scenario. Europe and North America are particularly sensitive to the climate and socioeconomic scenarios used, as can be seen in the large differences between the scenarios for these two regions. For North America, the costs vary between 4 and 7 billion US\$ depending on the scenario. The annual total cost of improved agriculture, set to $0.02 \mathrm{US} \$ / \mathrm{m}^{3}$, is less than 0.2 billion US $\$$, and therefore invisible in Fig. 4, except for Asia, where large areas are irrigated with river water and the costs for the $200 \mathrm{~km}^{3} / \mathrm{y}$ that can be gained from improved agriculture amount to $2-3$ billion US\$. Absolute cost (Fig. S9) shows a similar pattern, but with a larger range of values as surface areas differed between the water provinces, leading to larger total costs for larger water provinces.

\subsection{Web-based simulation of adaptation options}

The input data for each of the water provinces was based on global datasets, but obviously lacks features and specifics that can be influential for the water resources system on the water province- and basinlevel. Therefore, a regional case study was done to compare results with locally-sourced information, serving as a first-order evaluation of the tool. This first-order evaluation took place for the Segura-Jucar basin, southeastern Spain (Buitink et al., 2016). As expected, incorporating locally-sourced information can have a major impact on the water gap assessments at this spatial level.

The demonstration of the web-based application (Fig. 5) shows the typical workflow for the calculation of the WMCC. First, one selects the water province under consideration. In this case, the water province around Valencia in Spain (Fig. 5B), which includes the Segura and the Jucar basins. Secondly, one chooses the RCP and SSP scenario and sets the magnitude of the eight different adaptation options (Fig. 5A, left panel). In this example, we selected the RCP4.5 and SSP5 scenario (Fig. 5A top left). Thirdly, WatCAM is run and the climate change and impact panel gets activated with the projections climate change (temperature and precipitation) and impact (the water demand and supply) until 2100 (Fig. 5A, right panel). For the water province around Valencia it shows an increase in temperature $\left(\sim 2{ }^{\circ} \mathrm{C}\right)$ and a decrease in precipitation $(\sim 90 \mathrm{~mm})$, and the water gap is projected to increase over the 21 st century due to climate and socio-economic changes. The default configuration for this water province does not include the interbasin water transfer from the Tagus, which drains towards the west. The transfer consists of around $300 \mathrm{MCM} / \mathrm{y}$, which translates to $9.5 \mathrm{~m}^{3} / \mathrm{s}$ on average, which was added to the natural external flow of $2.1 \mathrm{~m}^{3} / \mathrm{s}$ totaling $11.6 \mathrm{~m}^{3} / \mathrm{s}$ (Fig. 5A). The web-based simulation enables the manual inclusion of such local knowledge by increasing the external flow. This example shows that the set of eight measures almost closes the water gap around 2050 (Fig. 5C, top panel), but additional measures will be required towards the end of the century (Fig. 5C, bottom panel. Moreover, closing the water completely is shown to be extremely costly. Comparing the yearly costs of closing the current water gap $\left(\sim 3 \cdot 10^{9}\right.$ USD/year) with past investments in water infrastructure (pipes and transfer systems) by the Jucar basin authority (Sevilla and Torregrosa, 2011; Table 1) that amount to $0.5 \cdot 10^{9} € /$ year under a life expectancy of 60 years, suggest that these are in the right order of magnitude. 


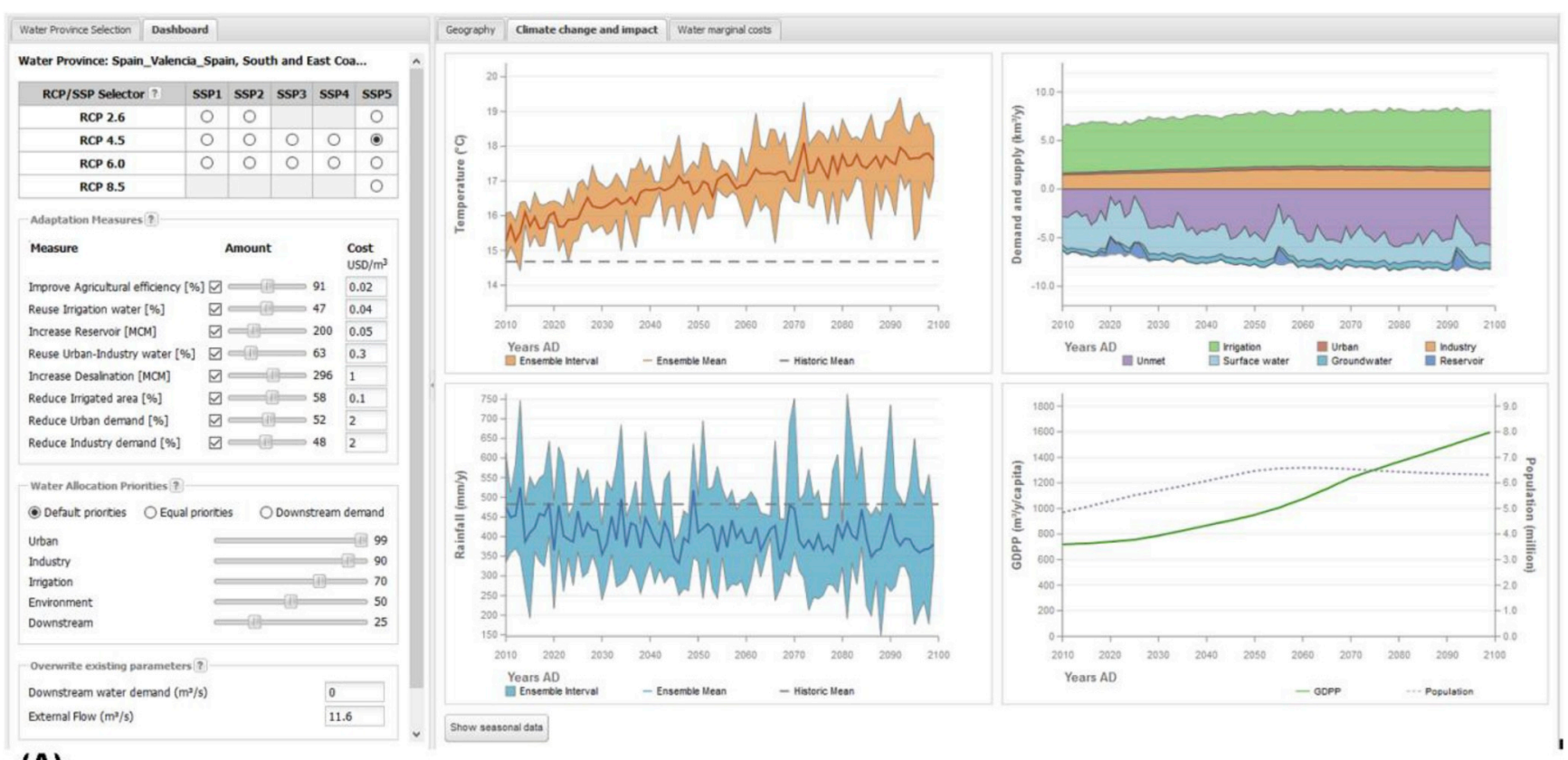

\section{(A)}
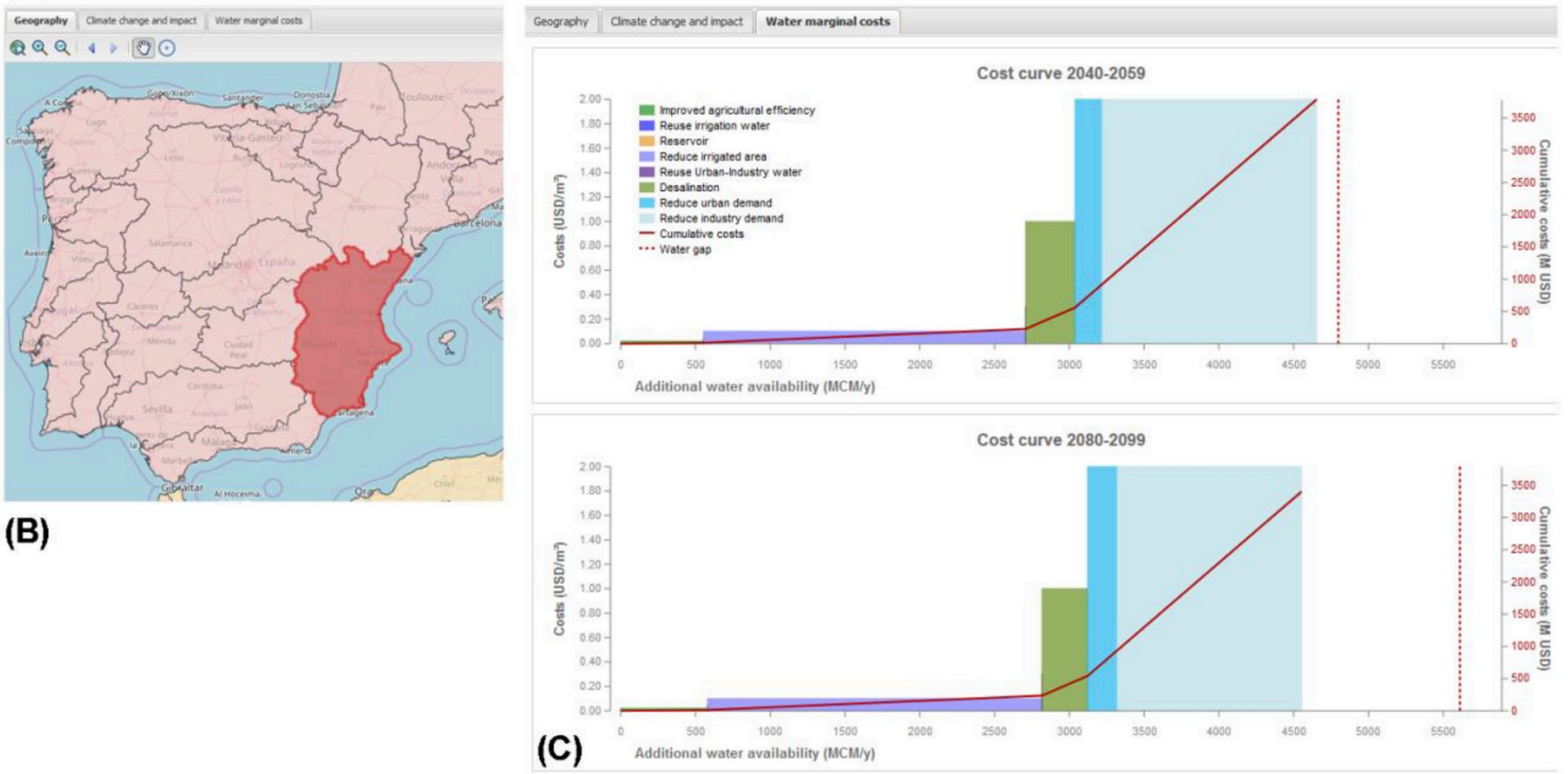

Fig. 5. Example output from the web service, available at http://w2i.geo.uu.nl. A) Climate and socio-hydrologic changes under SSP5 and RCP4.5b) the water province of Valencia in Spain. The annual average temperature increases and the precipitation decreases, which - combined with an increasing GPD and a stabilizing population size - leads to an increasing water gap. C) The selected measures almost close the water gap around 2050, but not around 2090.

Table 2

Projections of key adaptation indicators for the water province of the Segura and Jucar basins around the year 2090, with respect to the water gap ('Gap' in MCM/y), the reduction of the water gap due to the nine adaptation options as shown in Fig. 5 ('Red.' In MCM/y), and the total annual costs for the nine options ('Cost' in M USD). Shaded cells indicate scenarios where the reduction exceeds the water gap.

\begin{tabular}{|c|c|c|c|c|c|c|c|c|c|c|c|c|c|c|c|}
\hline SSP -> & SSP1 & & & SSP2 & & & SSP3 & & & SSP4 & & & SSP5 & & \\
\hline RCP & Gap & Red. & Cost & Gap & Red. & Cost & Gap & Red. & Cost & Gap & Red. & Cost & Gap & Red. & Cost \\
\hline RCP2.6 & 2431 & 5619 & 4430 & 2348 & 5584 & 4268 & --- & --- & --- & --- & --- & --- & 3055 & 5797 & 5421 \\
\hline RCP4.5 & 4894 & 4262 & 2751 & 4799 & 4230 & 2670 & 4182 & 4042 & 2112 & 5594 & 4546 & 3388 & 5611 & 4553 & 3402 \\
\hline RCP6.0 & 4452 & 4144 & 2645 & 4359 & 4102 & 2549 & 3749 & 3820 & 1893 & 5130 & 4476 & 3370 & 5147 & 4483 & 3388 \\
\hline RCP8.5 & --- & --- & --- & --- & --- & -- & --- & --- & --- & --- & --- & --- & 7380 & 4771 & 3226 \\
\hline
\end{tabular}


The web interface enables the comparison of different RCP and SSP scenarios by direct download of the projections of key adapation indicators, including annual costs, the water gap and the water gap reduction (Table 2). For the Segura-Jucar, it showed that the water gap could be closed in the RCP2. 6 with eight different adaptations, but in the other RCP scenarios a water gap will remain. Note that the water gap is larger in the RCP4.5 scenario than in the RCP6.0 scenario, but that the values are also close to each other. This can be attributed to a larger rainfall amount in the RCP6.0 GCM output.

\section{Discussion}

We presented a modelling framework that allows an integrated global or regional assessment of the gap between water supply and demand, the effectiveness of adaptation options in reducing this gap and their costs as fraction of GDP. The global application builds on previous work that provided more detail on specific components of our integrated assessment, such as water scarcity (Wada et al., 2011b; Schewe et al., 2014; Veldkamp et al., 2016), food security (Hanjra and Qureshi, 2010; Wheeler and von Braun, 2013), and to a lesser extent environmental flows (Smakhtin, 2008; Pastor et al., 2014) as we are at the lower end of the suggested mean annual flow and do not take varying flow into account. The cost and effectiveness of adaptation options provide important input to the discussion on the allocation of climate change adaptation funds. The UNFCC Green Climate Fund aims to raise 100 billion US\$ annually for climate change adaptation and mitigation (Donner et al., 2011). While this goal has yet to be reached, our results show that it would barely be sufficient to fund our estimate of costs (78-115 billion US\$) for the three measures simulated under RCP2.6 and SP1 projections, but this would be far from closing the projected water gap. The current water gap of $6.010^{2} \mathrm{~km}^{3} / \mathrm{y}$ is based on close-to-sustainable water usage and includes environmental flow requirements, which are assumed to amount to $20 \%$ of the mean monthly naturalized flow (i.e. without human water withdrawal). This water gap exceeds the global water gap reported by Wada et al. (2011b) in the form of extractions of non-renewable groundwater of $310 \mathrm{~km}^{3} / \mathrm{y}$, because we include environmental flow. We argue that taking the environmental flows into account is crucial because of their direct benefits such as reduced sediment supply to deltas (Syvitski et al., 2009), the high stress on wetland ecosystems (Tessler et al., 2015), and the extinction of freshwater species (Ricciardi and Rasmussen, 1999).

Decisions on adaptation are taken under large uncertainties, especially when the longevity of the infrastructure that is built spans a century, such as is the case for dams and reservoirs. Previous studies addressed more detailed analyses of climate change adaptation for industrial and municipal sectors (Ward et al., 2010) (10 billion USD/y), or calculated the adaptation cost of climate and socioeconomic change (Kirshen, 2017) from 2000 till 2030 (18 billion USD/y). In this study, we integrated climate change (RCP2.6 and RCP8.5) and socioeconomic change (SSP1 and SSP5) for 1604 water provinces giving total adaptation costs of 50 and 79 billion USD/y for the Red.Dem adaptations and the s1 and s5 scenario, respectively. These are in the same order of magnitude, but higher as we included demands from environmental flow as well. We would argue that complete closure of the water gap at the global scale should not be the main goal. The monthly water supply is affected by the weather and interannual variations in precipitation and temperature (Adler et al., 2008). Periods of limited water supply should be factored in to avoid over-dimensioning the water infrastructure during average years. Moreover, full closure of the water gap may not be economically optimal when both costs and benefits are considered.

We included both the magnitude and the possible reduction of the water gap on a global scale with 2100 as the temporal horizon. In such integrated long term assessments, the resulting uncertainty in the WMCC has five main sources that are partially addressed by other studies: global climate models (Knutti and Sedlacek, 2013), global hydrological models (Prudhomme et al., 2014), the combination of the two (Schewe et al., 2014), RCP and SSP scenario uncertainty, and the cost of adaptation options. For the results presented here, we simulated the two extreme ends of the RCP-SSP scenario spectrum to place bounds on the scenario uncertainty. The other sources of uncertainty were out of scope for this study. A large uncertainty remains in quantifying the adaptation costs as this information is not globally available. We used uniform costs for the three measure sets, but a detailed overview of adaptation options for China, India, Brazil, and South Africa showed large differences between the countries (2030WRG, 2009). They showed a range of options for improved irrigation with cost ranging from -0.05 $\$ / \mathrm{m}^{3}$ for no-till farming to +0.03 for increased fertilizer use. Measures like no-till farming and limiting over-irrigation even generate a benefit. Clearly, local knowledge could substantially improve quantification of the total cost of these measures for a specific water province. Our web tool enables the compilation of selected adaptation options, using local costs for each water province separately, as well as local information on interbasin water transfer and river flow obligations from water treaties. As such, bringing water resources management to the web opens new options for human computation approaches, such as crowd sourcing, serious games, human sensors, or social mobilization (Fraternali et al., 2012).

The case study of the water province around Valencia in Spain showed the projected water gap and the WMCC around 2050 and 2090. The annual costs of the combined adaptations were comparable in order of magnitude of investments previously made (Sevilla and Torregrosa, 2011). Further evaluation could be achieved by driving an existing decision support system, such as shown by Pedro-Monzonís et al. (2016) for the Velez river in Spain, with the same external forcing and adaptations. However, these are currently not available. As such, the current outcomes should not be considered sufficiently accurate for final decision making at local level. Further validation and the inclusion of more datasets is needed to validate the water marginal cost curves at the level of a water province.

We showed that it is not possible to close the water gap if environmental flow requirements are taken into account and requiring water usage to be close to sustainable levels of groundwater withdrawal. The adaptation costs comprise a significant portion of the GDP. How effective countries will be in addressing their needs for water depends on effectiveness of institutions and levels of government spending amongst others (Noy, 2009). It should be noted that we have only looked at non-extreme adaptation options, while additional and more costly options are available such as large scale interbasin water transfer. These options are not implemented in the current framework. Other more expensive solutions may be to invest in large-scale desalination and conjunctive groundwater and surface water use in combination with managed aquifer recharge. Population size is the main driver of water demand, either directly through domestic water demand, or indirectly through food and energy production. Limiting population growth will directly decrease the future water gap.

Our global and web-based adaptation framework provides a first step in the integrated assessment of measures to reduce the water gap in a regional setting, which could be developed further in several ways. Firstly, the timing of the measure implementation could be optimized. In the current approach all measures are implemented from the start to evaluate what measures suffice, but future implementations could be more efficient by assessing the optimal moment in time for the implementation given the uncertainties in the projections (Kind, 2014). Secondly, water allocation could be optimized by taking into account the economic effects of water shortage in the different sectors (George et al., 2011) including both costs and benefits of investment sets using cost-benefit analysis (Mechler, 2016) or more advanced methods (Watkiss et al., 2015) to guide the optimal selection. Thirdly, positioning of the measures within a basin could be included in the optimization, because downstream water scarcity strongly depends on upstream usage (Veldkamp et al., 2017; Munia et al., 2018; Wheeler et al., 2018). 
Fourthly, a sensitivity analysis could shed light on the dependence of the water availability on water province size, the priorities of water allocation, or the including the additional evaporation from reservoirs. Fifthly, using an extended cost model, i.e. one that includes opportunity costs and economic and environmental externalities (Rogers et al., 1998), would allow for selecting adaptation sets that are socially optimal. Finally, including behavioral modelling (Sivapalan et al., 2011) to include stakeholder preferences and uptake of adaptation options would greatly enhance the local applicability of the framework. We note however, that these developments require much more data, such that we foresee their implementation for local applications using the web-tool, not for global applications.

The relatively parsimonious economic modelling using WMCCs as well as the simple setup of WatCAM is to provide a first order estimate of the hydrologic-economic system. Including more complex hydroeconomic modelling could improve the accuracy and the level of detail. Two further lines of development are recommended. Firstly, the PCR-GLOBWB global hydrology and water resources model could be used to model both supply and demand, but parallel computation of routing and accumulating water over the rasterized drainage network is required to limit the response time in the web interface to a few minutes. PCRaster currently enables parallel computation of point operations and scales across multiple nodes in a computer cluster, but hydrological operations are not yet supported. Similarly, the pangeo-project (http ://pangeo-data.org/) aims at high performance computing, but these Python-based packages also cannot yet deal with hydrological functions either. Secondly the network of water provinces could be replaced with a node-link network of the river topology and water infrastructure. The global vector-based model of Lin et al. (2018) could provide the river network, but the water demand network should still be developed. Lastly, the web-based simulation could be integrated with online collaboration platforms, e.g. Hydroshare (Yi et al., 2018), virtual globes (Veenendaal et al., 2017), ArcGIS-online, or Geonode to facilitate sharing of data and services. Ideally, all these tools would come together in a global integrated environmental model to support decision making, such as envisioned by Laniak et al. (2013).

\section{Conclusions}

With the framework presented in this study we can answer two key questions. Firstly, what is the magnitude and the global spatial distribution of the future water gap and what reduction can be achieved with adaptation options and at what costs? The global assessment showed a number of hotspots of water scarcity, most notably in the Mediterranean, the Mid-West in the USA and in India and Pakistan. The combination of mitigating climate change (i.e. staying on the RCP2.6 scenario, s1) and adaptation (Red.Dem. adaptation) lowers the 20-year average water gap from $759 \mathrm{~km}^{3} / \mathrm{y}$ in 2015 to $605 \mathrm{~km}^{3} / \mathrm{y}$ in 2090 . The median annual adaptation costs amount to $1.4-1.6 \%$ of the GDP of the affected water provinces. The second question is how we can enable decision makers through a web-based modelling environment to evaluate regional investment scenarios to close the water gap? The computational framework was made available through a web interface, which determines the climate change and impacts for a specific water province plus the water marginal cost curves projected to 2050 and 2090. Further downscaling towards local relevance requires the change to a node-link network of supply and demands and water allocation via rights or licenses, the operation the operations of water infrastructure and management decisions, and at the scale of the river basin. Our assessment of the future water gap and the effectiveness and costs of a range of adaptation options provides important information to support the dialogue on climate change adaptation funding.

\section{Software availability}

Name of the software: PCR-GLOBWB.
Name of the developers: Rens van Beek, Edwin Sutanudjaja, Marc Bierkens.

Contact information: Edwin Sutanudjaja, e.h.sutanudjaja@uu.nl.

Hardware required: High performance cluster for global scale assessment at 5' resolution and multiple forcings.

Programming languages: Python and PCRaster.

License: GPL-3, see https://github.com/UU-Hydro/PCR-GLO BWB_model.

Name of the software: WatCAM.

Name of the developers: Johannes Hunink, Peter Droogers, Joost Buitink.

Contact information: Johannes Hunink, Johannes.hunink@futur ewater.nl.

Hardware required: high-end desktop computer.

Programming languages: Python.

License: GPL-3, see https://github.com/FutureWater/WatCAM.

\section{Acknowledgements}

The authors acknowledge the ISI-MIP intercomparison project for providing the bias-corrected meteorological data of five global circulation models. This project was partly funded by EIT's Climate-KIC program: for Water2Invest, reference number APIN0027. This study's calculations with PCR-GLOBWB were computed on the Dutch national supercomputer Cartesius, with the support of SURFsara. The two reviewers are gratefully acknowledged their time and high-quality feedback, which significantly improved the manuscript. Author contributions: MWS, PD, RvB, MB designed the research; MWS, WBe, JB, $\mathrm{WBu}, \mathrm{OS}, \mathrm{PD}, \mathrm{DK}, \mathrm{ES}, \mathrm{CV}, \mathrm{RvB}$ implemented parts of the model code; MWS, JB, JH analyzed the data; MWS, MB, DK wrote the paper; MWS, $\mathrm{MB}, \mathrm{JH}, \mathrm{JB}, \mathrm{PD}$ wrote the supplemental information.

\section{Appendix A. Supplementary data}

Supplementary data to this article can be found online at https://doi. org/10.1016/j. envsoft.2019.104578.

\section{References}

Döll, P., Siebert, S., 2002. Global modeling of irrigation water requirements. Water Resour. Res. 38, 8-1-8-10.

Hanasaki, N., Fujimori, S., Yamamoto, T., Yoshikawa, S., Masaki, Y., Hijioka, Y., Kainuma, M., Kanamori, Y., Masui, T., Takahashi, K., Kanae, S., 2013. A global water scarcity assessment under Shared Socio-economic Pathways - Part 1: water use. Hydrol. Earth Syst. Sci. 17, 2375-2391.

Hanasaki, N., Fujimori, S., Yamamoto, T., Yoshikawa, S., Masaki, Y., Hijioka, Y., Kainuma, M., Kanamori, Y., Masui, T., Takahashi, K., Kanae, S., 2013. A global water scarcity assessment under Shared Socio-economic Pathways - Part 2: water availability and scarcity. Hydrol. Earth Syst. Sci. 17, 2393-2413.

2030WRG, 2009 2030WRG, 2009. Charting our water future: economic frameworks to inform decision-making. In: 2030 Water Resources Group, p. 198.

Adler, R.F., Gu, G., Wang, J.-J., Huffman, G.J., Curtis, S., Bolvin, D., 2008. Relationships between global precipitation and surface temperature on interannual and longer timescales (1979-2006). J. Geophys. Res.: Atmosph. 113.

Alcamo, J., Döll, P., Henrichs, T., Kaspar, F., Lehner, B., Rösch, T., Siebert, S., 2003. Global estimates of water withdrawals and availability under current and future "business-as-usual" conditions. Hydrol. Sci. J. 48, 339-348.

Ames, D.P., Horsburgh, J.S., Cao, Y., Kadlec, J., Whiteaker, T., Valentine, D., 2012. HydroDesktop: web services-based software for hydrologic data discovery, download, visualization, and analysis. Environ. Model. Softw 37, 146-156.

Arampatzis, G., Angelis-Dimakis, A., Blind, M., Assimacopoulos, D., 2016. A web-based Toolbox to support the systemic eco-efficiency assessment in water use systems. J. Clean. Prod. 138, 181-194.

Buitink, J., Hunink, J.E., Droogers, P., Torfs, P., 2016. Large Scale Adaptation Strategies to Climate Change in the Water Sector: an Overview of the Water Allocation Model WatCAM. FutureWater, Wageningen, p. 49.

Buytaert, W., Baez, S., Bustamante, M., Dewulf, A., 2012. Web-based environmental simulation: bridging the gap between scientific modeling and decision-making. Environ. Sci. Technol. 46, 1971-1976.

Byrne, J., Heavey, C., Byrne, P.J., 2010. A review of Web-based simulation and supporting tools. Simul. Model. Pract. Theory 18, 253-276.

Cetinkaya, C.P., Fistikoglu, O., Harmancioglu, N.B., Fedra, K., 2008. Optimization methods applied for sustainable management of water-scarce basins. J. Hydroinf. 10, 69-95. 
Dalin, C., Wada, Y., Kastner, T., Puma, M.J., 2017. Groundwater depletion embedded in international food trade. Nature 543, 700-704.

DHI, 2012. MIKE-BASIN User Manual. DHI, Hørsholm, p. 298.

Donner, S.D., Kandlikar, M., Zerriffi, H., 2011. Preparing to manage climate change financing. Science 334, 908-909.

Droogers, P., Immerzeel, W.W., Terink, W., Hoogeveen, J., Bierkens, M.F.P., van Beek, L P.H., Debele, B., 2012. Water resources trends in Middle East and North Africa towards 2050. Hydrol. Earth Syst. Sci. 16, 3101-3114.

ESRI, 2011. World Adminstrative Divisions. ESRI.

Falloon, P., Betts, R., 2010. Climate impacts on European agriculture and water management in the context of adaptation and mitigation-the importance of an integrated approach. Sci. Total Environ. 408, 5667-5687.

FAO-AQUASTAT, 2016. AQUASTAT Water Database. FAO.

Fischer, G., Tubiello, F.N., van Velthuizen, H., Wiberg, D.A., 2007. Climate change impacts on irrigation water requirements: effects of mitigation, 1990-2080 Technol. Forecast. Soc. Chang. 74, 1083-1107.

Fraternali, P., Castelletti, A., Soncini-Sessa, R., Vaca Ruiz, C., Rizzoli, A.E., 2012. Putting humans in the loop: social computing for water resources management. Environ. Model. Softw 37, 68-77.

Gain, A.K., Wada, Y., 2014. Assessment of future water scarcity at different spatial and temporal scales of the brahmaputra river basin. Water Resour. Manag. 28, 999-1012.

George, B., Malano, H., Davidson, B., Hellegers, P., Bharati, L., Massuel, S., 2011. An integrated hydro-economic modelling framework to evaluate water allocation strategies I: model development. Agric. Water Manag. 98, 733-746.

Goodall, J.L., Robinson, B.F., Castronova, A.M., 2011. Modeling water resource systems using a service-oriented computing paradigm. Environ. Model. Softw 26, 573-582.

Goodall, J.L., Saint, K.D., Ercan, M.B., Briley, L.J., Murphy, S., You, H., DeLuca, C., Rood, R.B., 2013. Coupling climate and hydrological models: interoperability through web services. Environ. Model. Softw 46, 250-259.

GRDC, 2016. Long-term mean monthly discharges and annual characteristics of GRDC station/Global Runoff Data Centre. In: Koblenz (Ed.), Germany: BfG (Global Runoff Data Centre).

Greve, P., Kahil, T., Mochizuki, J., Schinko, T., Satoh, Y., Burek, P., Fischer, G., Tramberend, S., Burtscher, R., Langan, S., Wada, Y., 2018. Global assessment of water challenges under uncertainty in water scarcity projections. Nat. Sustain. 1, 486-494.

Haddeland, I., Heinke, J., Biemans, H., Eisner, S., Flörke, M., Hanasaki, N., Konzmann, M., Ludwig, F., Masaki, Y., Schewe, J., Stacke, T., Tessler, Z.D., Wada, Y., Wisser, D., 2014. Global water resources affected by human interventions and climate change. Proc. Natl. Acad. Sci. 111, 3251-3256.

Hallegatte, S., 2009. Strategies to adapt to an uncertain climate change. Glob. Environ. Chang. 19, 240-247.

Hanasaki, N., Kanae, S., Oki, T., Masuda, K., Motoya, K., Shirakawa, N., Shen, Y., Tanaka, K., 2008. An integrated model for the assessment of global water resources Part 2: applications and assessments. Hydrol. Earth Syst. Sci. 12, 1027-1037.

Hanasaki, N., Yoshikawa, S., Kakinuma, K., Kanae, S., 2016. A seawater desalination scheme for global hydrological models. Hydrol. Earth Syst. Sci. 20, 4143-4157.

Hanjra, M.A., Qureshi, M.E., 2010. Global water crisis and future food security in an era of climate change. Food Policy 35, 365-377.

Hellegers, P.J.G.J., 2006. The role of economics in irrigation water management. Irrig. Drain. 55, 157-163.

Hempel, S., Frieler, K., Warszawski, L., Schewe, J., Piontek, F., 2013. A trend-preserving bias correction - the ISI-MIP approach. Earth Syst. Dyn. 4, 219-236.

IIASA, 2015. SSP Database 2012-2015. IIASA.

Immerzeel, W.W., Droogers, P., Terink, W., Hoogeveen, J., Hellegers, P., Bierkens, M.F. P., Van Beek, L.P.H., 2011. Middle-East and Northern Africa Water Outlook. FutureWater, Wageningen, p. 136.

Jägermeyr, J., Gerten, D., Heinke, J., Schaphoff, S., Kummu, M., Lucht, W., 2015. Water savings potentials of irrigation systems: global simulation of processes and linkages. Hydrol. Earth Syst. Sci. 19, 3073-3091.

Kind, J.M., 2014. Economically efficient flood protection standards for The Netherlands. J. Flood Risk Manag. 7, 103-117.

Kirshen, P., 2017. Adaptation Options and Cost in Water Supply. UNFCC, p. 57.

Knutti, R., Sedlacek, J., 2013. Robustness and uncertainties in the new CMIP5 climate model projections. Nat. Clim. Chang. 3, 369-373.

Kummu, M., Guillaume, J.H.A., de Moel, H., Eisner, S., Flörke, M., Porkka, M., Siebert, S., Veldkamp, T.I.E., Ward, P.J., 2016. The world's road to water scarcity: shortage and stress in the 20th century and pathways towards sustainability. Sci. Rep. 6, 38495.

Laniak, G.F., Olchin, G., Goodall, J., Voinov, A., Hill, M., Glynn, P., Whelan, G., Geller, G., Quinn, N., Blind, M., Peckham, S., Reaney, S., Gaber, N., Kennedy, R., Hughes, A., 2013. Integrated environmental modeling: a vision and roadmap for the future. Environ. Model. Softw 39, 3-23.

Lehner, B., Verdin, K., Jarvis, A., 2008. New global hydrography derived from spaceborne elevation data. Eos Trans. AGU 89, 93-94.

Lin, P., Yang, Z.-L., Gochis, D.J., Yu, W., Maidment, D.R., Somos-Valenzuela, M.A., David, C.H., 2018. Implementation of a vector-based river network routing scheme in the community WRF-Hydro modeling framework for flood discharge simulation. Environ. Model. Softw 107, 1-11.

Mechler, R., 2016. Reviewing estimates of the economic efficiency of disaster risk management: opportunities and limitations of using risk-based cost-benefit analysis. Nat. Hazards 81, 2121-2147.

Miina, P., Dieter, G., Sibyll, S., Stefan, S., Matti, K., 2016. Causes and trends of water scarcity in food production. Environ. Res. Lett. 11, 015001.
Munia, H.A., Guillaume, J.H.A., Mirumachi, N., Wada, Y., Kummu, M., 2018. How downstream sub-basins depend on upstream inflows to avoid scarcity: typology and global analysis of transboundary rivers. Hydrol. Earth Syst. Sci. 22, 2795-2809.

Noy, I., 2009. The macroeconomic consequences of disasters. J. Dev. Econ. 88, 221-231.

OECD, 2016. Education at a Glance: OECD Indicators. OECD, Paris, p. 505.

Pastor, A.V., Ludwig, F., Biemans, H., Hoff, H., Kabat, P., 2014. Accounting for environmental flow requirements in global water assessments. Hydrol. Earth Syst. Sci. 18, 5041-5059.

Pedro-Monzonís, M., Jiménez-Fernández, P., Solera, P., Jiménez-Gavilán, P., 2016. The use of AQUATOOL DSS applied to the System of Environmental-Economic Accounting for Water (SEEAW). J. Hydrol. 533, 1-14. https://doi.org/10.1016/j.jh ydrol.2015.11.034.

Portmann, F.T., Siebert, S., Döll, P., 2010. MIRCA2000—global monthly irrigated and rainfed crop areas around the year 2000: a new high-resolution data set for agricultural and hydrological modeling. Glob. Biogeochem. Cycles 24, GB1011.

Prudhomme, C., Giuntoli, I., Robinson, E.L., Clark, D.B., Arnell, N.W., Dankers, R., Fekete, B.M., Franssen, W., Gerten, D., Gosling, S.N., Hagemann, S., Hannah, D.M., Kim, H., Masaki, Y., Satoh, Y., Stacke, T., Wada, Y., Wisser, D., 2014. Hydrological droughts in the 21st century, hotspots and uncertainties from a global multimodel ensemble experiment. Proc. Natl. Acad. Sci. 111, 3262-3267.

Rajib, M.A., Merwade, V., Kim, I.L., Zhao, L., Song, C., Zhe, S., 2016. SWATShare - a web platform for collaborative research and education through online sharing, simulation and visualization of SWAT models. Environ. Model. Softw 75, 498-512.

Ricciardi, A., Rasmussen, J.B., 1999. Extinction rates of North American freshwater fauna. Conserv. Biol. 13, 1220-1222.

Rogers, P., Bhatia, R., Huber, A., 1998. Water as a Social and Economic Good: How to Put the Principle into Practice (Working Paper). Global Water Partnership/Swedish International Development Agency, Stockholm, p. 39.

Scanlon, B.R., Jolly, I., Sophocleous, M., Zhang, L., 2007. Global impacts of conversions from natural to agricultural ecosystems on water resources: quantity versus quality. Water Resour. Res. 43, W03437.

Schewe, J., Heinke, J., Gerten, D., Haddeland, I., Arnell, N.W., Clark, D.B., Dankers, R., Eisner, S., Fekete, B.M., Colón-González, F.J., Gosling, S.N., Kim, H., Liu, X., Masaki, Y., Portmann, F.T., Satoh, Y., Stacke, T., Tang, Q., Wada, Y., Wisser, D., Albrecht, T., Frieler, K., Piontek, F., Warszawski, L., Kabat, P., 2014. Multimodel assessment of water scarcity under climate change. Proc. Natl. Acad. Sci. 111, 3245-3250.

Sege, J., Ghanem, M., Ahmad, W., Bader, H., Rubin, Y., 2018. Distributed data collection and web-based integration for more efficient and informative groundwater pollution risk assessment. Environ. Model. Softw 100, 278-290.

Sevilla, M., Torregrosa, T., 2011. Justification of public investment initiatives on water transfer systems as an instrument for water balances in Spain: the case of the Júcar-Vinalopó water transfer system. Agric. Sci. 2, 518-525.

Shen, Y., Oki, T., Utsumi, N., Kanae, S., Hanasaki, N., 2008. Projection of future world water resources under SRES scenarios: water withdrawal/Projection des ressources en eau mondiales futures selon les scénarios du RSSE: prélèvement d'eau. Hydrol. Sci. J. 53, 11-33.

Sivapalan, M., Savenije, H.H.G., Blöschl, G., 2011. Socio-hydrology: a new science of people and water. Hydrol. Process. 26, 1270-1276.

Smakhtin, V., 2008. Basin closure and environmental flow requirements. Int. J. Water Resour. Dev. 24, 227-233.

Smakhtin, V.U., Eriyagama, N., 2008. Developing a software package for global desktop assessment of environmental flows. Environ. Model. Softw 23, 1396-1406.

Sutanudjaja, E.H., van Beek, R., Wanders, N., Wada, Y., Bosmans, J.H.C., Drost, N., van der Ent, R.J., de Graaf, I.E.M., Hoch, J.M., de Jong, K., Karssenberg, D., López López, P., Peßenteiner, S., Schmitz, O., Straatsma, M.W., Vannametee, E., Wisser, D., Bierkens, M.F.P., 2018. PCR-GLOBWB 2: a 5 arcmin global hydrological and water resources model. Geosci. Model Dev. (GMD) 11, 2429-2453.

Syvitski, J.P.M., Kettner, A.J., Overeem, I., Hutton, E.W.H., Hannon, M.T., Brakenridge, G.R., Day, J., Vorosmarty, C., Saito, Y., Giosan, L., Nicholls, R.J., 2009. Sinking deltas due to human activities. Nat. Geosci. 2, 681-686.

Taylor, K.E., Stouffer, R.J., Meehl, G.A., 2012. An overview of CMIP5 and the experiment design. Bull. Am. Meteorol. Soc. 93, 485-498.

Temmerman, S., Meire, P., Bouma, T.J., Herman, P.M.J., Ysebaert, T., De Vriend, H.J., 2013. Ecosystem-based coastal defence in the face of global change. Nature 504, $79-83$.

Tennant, D.L., 1976. Instream flow regimens for fish, wildlife, recreation and related environmental resources. Fisheries 1, 6-10.

Tessler, Z.D., Vörösmarty, C.J., Grossberg, M., Gladkova, I., Aizenman, H., Syvitski, J.P. M., Foufoula-Georgiou, E., 2015. Profiling risk and sustainability in coastal deltas of the world. Science 349, 638-643.

Trieb, F., Müller-Steinhagen, H., 2008. European desalination society and center for research and technology hellas (CERTH), sani resort 22-25 april 2007, halkidiki, GreeceConcentrating solar power for seawater desalination in the Middle East and North Africa. Desalination 220, 165-183.

Van Beek, L.P.H., Wada, Y., Bierkens, M.F.P., 2011. Global monthly water stress: 1. Water balance and water availability. Water Resour. Res. 47.

van Vliet, M.T.H., Franssen, W.H.P., Yearsley, J.R., Ludwig, F., Haddeland, I., Lettenmaier, D.P., Kabat, P., 2013. Global river discharge and water temperature under climate change. Glob. Environ. Chang. 23, 450-464.

van Vuuren, D.P., Lucas, P.L., Hilderink, H., 2007. Downscaling drivers of global environmental change: enabling use of global SRES scenarios at the national and grid levels. Glob. Environ. Chang. 17, 114-130.

Veenendaal, B., Brovelli, M.A., Li, S., 2017. Review of web mapping: eras, trends and directions. ISPRS Int. J. Geo-Inf. 6. 
Veldkamp, T.I.E., Wada, Y., de Moel, H., Kummu, M., Eisner, S., Aerts, J.C.J.H., Ward, P. J., 2015. Changing mechanism of global water scarcity events: impacts of socioeconomic changes and inter-annual hydro-climatic variability. Glob. Environ. Chang. 32, 18-29.

Veldkamp, T.I.E., Wada, Y., Aerts, J.C.J.H., Ward, P.J., 2016. Towards a global water scarcity risk assessment framework: incorporation of probability distributions and hydro-climatic variability. Environ. Res. Lett. 11, 024006.

Veldkamp, T.I.E., Wada, Y., Aerts, J.C.J.H., Döll, P., Gosling, S.N., Liu, J., Masaki, Y., Oki, T., Ostberg, S., Pokhrel, Y., Satoh, Y., Kim, H., Ward, P.J., 2017. Water scarcity hotspots travel downstream due to human interventions in the 20th and 21st century. Nat. Commun. 8, 15697.

Vitolo, C., Elkhatib, Y., Reusser, D., Macleod, C.J.A., Buytaert, W., 2015. Web technologies for environmental big data. Environ. Model. Softw 63, 185-198.

Vörösmarty, C.J., Green, P., Salisbury, J., Lammers, R.B., 2000. Global water resources: vulnerability from climate change and population growth. Science 289, 284-288.

Vuuren, D.P., Kriegler, E., O’Neill, B.C., Ebi, K.L., Riahi, K., Carter, T.R., Edmonds, J., Hallegatte, S., Kram, T., Mathur, R., Winkler, H., 2014. A new scenario framework for Climate Change Research: scenario matrix architecture. Clim. Change 122, 373-386.

Wada, Y., Van Beek, L.P.H., Bierkens, M.F.P., 2011. Modelling global water stress of the recent past: on the relative importance of trends in water demand and climate variability. Hydrol. Earth Syst. Sci. 15, 3785-3808.

Wada, Y., van Beek, L.P.H., Viviroli, D., Dürr, H.H., Weingartner, R., Bierkens, M.F.P., 2011. Global monthly water stress: 2 . Water demand and severity of water stress. Water Resour. Res. 47, W07518.

Wada, Y., van Beek, L.P.H., Sperna Weiland, F.C., Chao, B.F., Wu, Y.-H., Bierkens, M.F.P., 2012. Past and future contribution of global groundwater depletion to sea-level rise. Geophys. Res. Lett. 39, L09402.
Wada, Y., Flörke, M., Hanasaki, N., Eisner, S., Fischer, G., Tramberend, S., Satoh, Y., van Vliet, M.T.H., Yillia, P., Ringler, C., Burek, P., Wiberg, D., 2016. Modeling global water use for the 21st century: the Water Futures and Solutions (WFaS) initiative and its approaches. Geosci. Model Dev. (GMD) 9, 175-222.

Walker, J.D., Chapra, S.C., 2014. A client-side web application for interactive environmental simulation modeling. Environ. Model. Softw 55, 49-60.

Ward, P.J., Strzepek, K.M., Pieter Pauw, W., Brander, L.M., Hughes, G.A., Aerts, J.C.J.H., 2010. Partial costs of global climate change adaptation for the supply of raw industrial and municipal water: a methodology and application. Environ. Res. Lett. $5,044011$.

Warszawski, L., Frieler, K., Huber, V., Piontek, F., Serdeczny, O., Schewe, J., 2014. The inter-sectoral impact model intercomparison project (ISI-MIP): project framework. Proc. Natl. Acad. Sci. 111, 3228-3232.

Watkiss, P., Hunt, A., Blyth, W., Dyszynski, J., 2015. The use of new economic decision support tools for adaptation assessment: a review of methods and applications, towards guidance on applicability. Clim. Change 132, 401-416.

WCoD, 2000. Dams and Development, a New Framework for Decision Making. Earthscan, London and Sterling, p. 404.

Wheeler, T., von Braun, J., 2013. Climate change impacts on global food security. Science 341, 508-513.

Wheeler, K.G., Hall, J.W., Abdo, G.M., Dadson, S.J., Kasprzyk, J.R., Smith, R., Zagona, E. A., 2018. Exploring cooperative transboundary river management strategies for the eastern nile basin. Water Resour. Res. 54, 9224-9254.

Yates, D.N., Sieber, J., Purkey, D.R., Huber-Lee, A., 2005. WEAP21 - a demand- , priority-, and preference-driven water planning model Part 1 : model characteristics. Water Int. 30, 487-500.

Yi, H., Idaszak, R., Stealey, M., Calloway, C., Couch, A.L., Tarboton, D.G., 2018. Advancing distributed data management for the HydroShare hydrologic information system. Environ. Model. Softw 102, 233-240. 